$$
\begin{aligned}
& \text { ANL KCMT ICP-- } 99579 \\
& \text { CONF-9608108--i }
\end{aligned}
$$

\title{
CORRODED SPENT NUCLEAR FUEL EXAMINED WITH EELS
}

\author{
Edgar C. Buck, Nancy L. Dietz, and John K. Bates \\ ARGONNE NATIONAL LABORATORY \\ Chemical Technology Division \\ 9700 South Cass Avenue \\ Argonne, IL 60439-4837
}

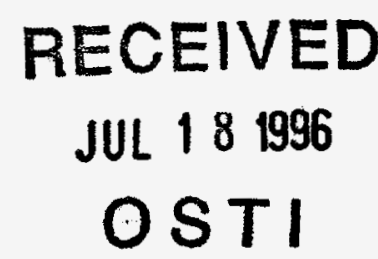

The submitted manuscript has been
authored by a contractor of the U.S.
Government under contract No. W-31-108-
ENG-38. Accordingly, the U.S. Government
retains a nonexclusive, royalty-free license
to publish or reproduce the published form of
this contribution, or allow others to do so, for
U.S. Government purposes.

Prepared for Presentation at

30th Annual Meeting of Microbeam Analysis Society

August 11-15, 1996

Minneapolis, Minnesota

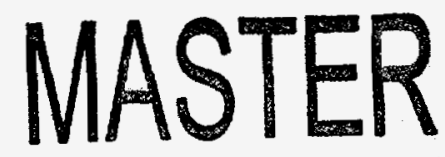

This work supported by the U.S. Department of Energy, Office of Environmental Management, under contract W-31-109-ENG-38. 


\section{DISCLAMMER}

This report was prepared as an account of work sponsored by an agency of the United States Government. Neither the United States Government nor any agency thereof, nor any of their employees, makes any warranty, express or implied, or assumes any legal liability or responsibility for the accuracy, completeness, or usefulness of any information, apparatus, product, or process disclosed, or represents that its use would not infringe privately owned rights. Reference herein to any specific commercial product, process, or service by trade name, trademark, manufacturer, or otherwise does not necessarily constitute or imply its endorsement, recommendation, or favoring by the United States Government or any agency thereof. The views and opinions of authors expressed herein do not necessarily state or reflect those of the United States Government or any agency thereof. 


\title{
CORRODED SPENT NUCLEAR FUEL EXAMINED WITH EELS
}

\author{
Edgar C. Buck, Nancy L. Dietz, and John K. Bates \\ Chemical Technology Division, Argonne National Laboratory, 9700 South Cass Avenue, Argonne, IL 60439
}

Direct disposal of spent nuclear fuel (SNF) into the proposed unsaturated geologic repository at Yucca Mountain, NV is being studied at several laboratories, including Argonne National Laboratory [1]. Corrosion tests with SNF are being conducted to understand the long-term behavior of SNF under conditions designed to simulate the unsaturated conditions at the site. The SNF used in this study was the Approved Testing Material (ATM)-106 with a burn-up of $43 \mathrm{MW} \cdot \mathrm{d} / \mathrm{kg} \mathrm{U}$ [2]. A sample of ATM106 fuel was exposed to dripping simulated groundwater for 271 days; after this time the experiment was terminated and the material removed for further study. Details of the testing methodology have been given by Finn et al. [1].

Previous attempts to study SNF with TEM have used ion milled samples [3], in this study we prepared the samples by ultramicrotomy which reduced the radiological hazard substantially. Particles of the reacted SNF were carefully removed from the surface with the aid of an optical microscope and diamond scribe and then embedded in a Medcast epoxy block. The selection of suitably sized particles ( $<5 \mu \mathrm{m}$ in diameter) and correct orientation was critical to producing usable ultramicrotomed thin sections of SNF for TEM (see Fig. 1a). We have successfully produced TEM thin sections which can be used for detailed EELS. Analyses were performed on a JEOL 2000FXII/ Gatan 666 PEELS with a $\mathrm{LaB}_{6}$ filament. The energy resolution was $1.6-1.8 \mathrm{eV}$.

Figure $1 \mathrm{~b}$ shows the reacted fuel and an attached alteration phase. The objective of the TEM investigations has been to determine the nature of SNF corrosion through the identification of alteration phases and determination of the distribution of neutron capture and fission products. The alteration phase was identified by electron diffraction, $x$-ray energy dispersive spectroscopy, and EELS as a layered cesium molybdenum uranyl oxide hydrate, structurally related to phases of the becquerelite group uranium minerals. These uranyl oxide hydrate alteration phases will control the solubility of uranium and, hence, determine the long-term durability of the solid SNF waste form.

The large number of elements in SNF can make TEM/EDS analysis a challenge. As well as removing channel-to-channel gain variation in parallel detectors, the second-difference EELS technique serves as a frequency filter that selectively enhances the high frequency features, such as the $\mathrm{M}_{4,5}$ absorption edges ("white lines") of rare earth elements (REE) and transuranics (TRU). In Figure 2, second-difference EELS of REE within the corroded particle of SNF is shown. The technique allows detection of REE that are present at $<20 \mathrm{ppm}$. In Figure $2 \mathrm{a}$, the TRU $\mathbf{M}_{4}$ and $\mathrm{M}_{5}$ edges, which correspond to $3 \mathrm{~d}_{3 / 2} \rightarrow 5 \mathrm{f}_{5 / 2}$ and $3 \mathrm{~d}_{5 / 2} \rightarrow 5 \mathrm{f}_{7 / 2}$ transitions, respectively, have been used to detect low levels of TRU in the SNF. Overlap of TRU $N_{4,5}$ edges with the more intense REE $M_{4,5}$ edges effectively excludes this lower energy region from being used. An extremely high intensity, coupled with relatively long integration times (5-20 s) and repetitive runs, can allow detection of individual TRU elements, $\mathrm{Np}, \mathrm{Pu}$, and Am (see Fig. 2b). The calculated concentrations of TRU elements in ATM-106 $\mathrm{SNF}$ are $2590 \mathrm{ppm} \mathrm{Pu}$ and $115 \mathrm{ppm}$ Am [2].

With ultramicrotomed TEM samples, we have been able to study a very hazardous material. The sections prepared were of such quality that highly detailed EELS analysis was possible allowing for the detection of low levels of transuranics in the reacted fuel. This work will assist in gaining an improved understanding of the corrosion mechanism of spent fuel in an aqueous environment [4].

References

[1] P. A. Finn et al., Radiochimica Acta, 66/67 (1994) 189

[2] R. J. Guenther et al., Characterization of Spent Fuel Approved Testing Material-ATM-106, Pacific Northwest Laboratory Report, PNL-5109-106 (1988)

[3] L. E. Thomas et al., J. Nucl. Mater., 166 (1989) 243 
[4] Spent fuel tests performed by P. A. Finn, D. J. Wronkiewicz, J. W. Emery, and J. C. Hoh. Work supported by the U.S. Department of Energy under contract W-31-109-ENG-38.

1a

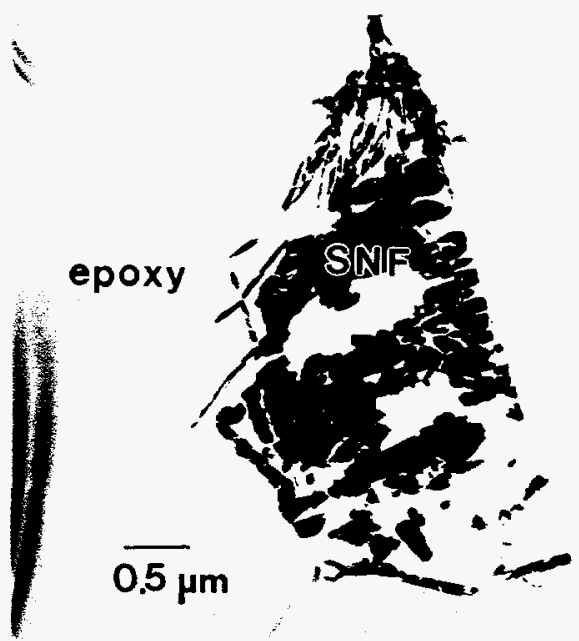

1b
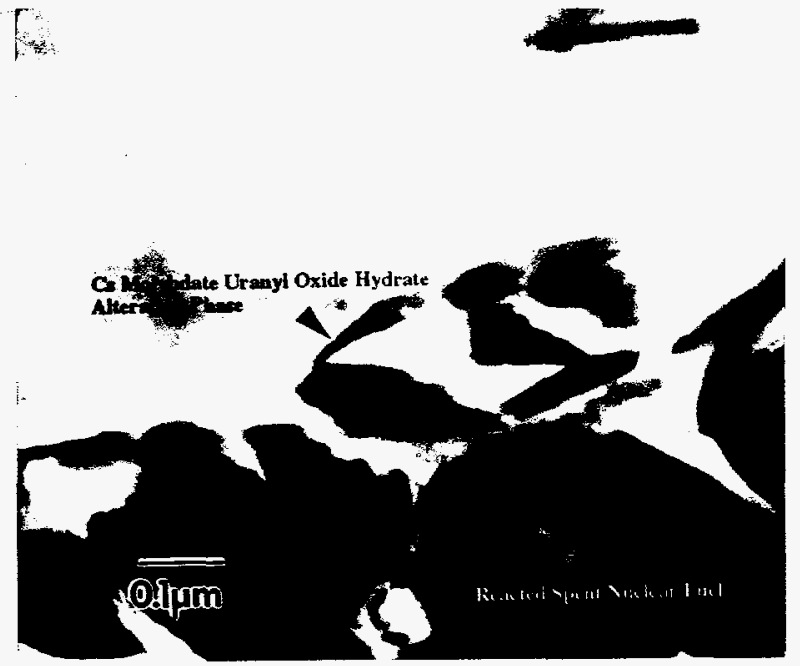

2b
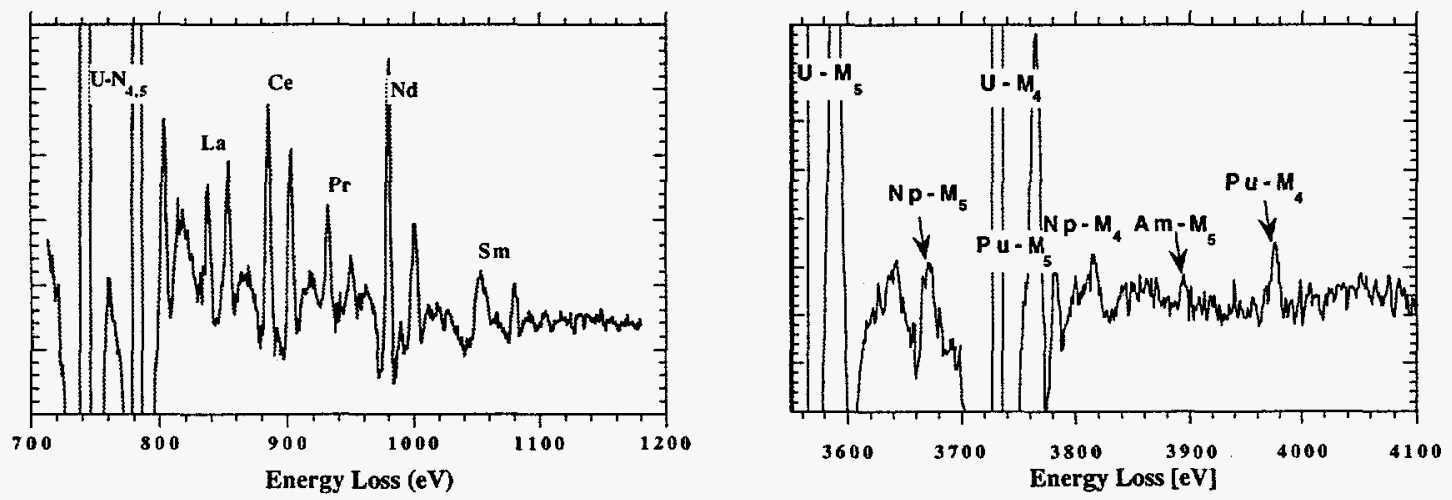

Fig. 1 (a) Low Magnification Image of Thin Sectioned SNF and (b) Image of Reacted SNF and attached Cs Mo Uranyl Oxide Alteration Phase.

Fig. 2 Second-Difference EELS of SNF Showing REE $\mathrm{M}_{4,5}$ edges of $\mathrm{La}, \mathrm{Ce}, \mathrm{Pr}, \mathrm{Nd}$, and $\mathrm{Sm}$. The major component of SNF, uranium, is visible in the two energy loss ranges analyzed. In (a) $\mathrm{N}_{4,5}$ edges of $U$ at $738 \mathrm{eV}$ and $780 \mathrm{eV}$ along with a number of REE and in (b) $M_{4,5}$ edges of $U$ at $M_{5}=3552 \mathrm{eV}$, $\mathrm{M}_{4}=3728 \mathrm{eV}$, along with the TRU elements, $\mathrm{Np}\left(\mathrm{M}_{5}=3666 \mathrm{eV}\right.$ and $\mathrm{M}_{4}=3850 \mathrm{eV}, \mathrm{Pu}\left(\mathrm{M}_{5}=3778\right.$ $\left.\mathrm{eV}, \mathrm{M}_{4}=3973 \mathrm{eV}\right)$, and $\mathrm{Am}\left(\mathrm{M}_{5}=3887 \mathrm{eV}, \mathrm{M}_{4}=4092 \mathrm{eV}\right)$. 